\title{
KONSEP KEBERSAMAAN DALAM FILM "AISYAH BIARKAN KAMI BERSAUDARA" KARYA HERWIN NOVIANTO
}

\section{THE CONCEPT OF TOGETHERNESS IN THE FILM "AISYAH BIARKAN KAMI BERSAUDARA" HERWIN NOVIANTO}

\author{
Susiati \\ Universitas Iqra Buru \\ Jalan Prof. Dr. H. A.R. Basalamah No. 20, Namlea, Buru \\ Telepon (0913) 21909, Pos-el: susiatiuniqbu@gmail.com
}

\begin{abstract}
Abstrak
Penelitian ini bertujuan mendeskripsikan konsep kebersamaan dalam film "Aisyah Biarkan Kami Bersaudara" karya Herwin Novianto. Penelitian ini merupakan penelitian kualitatif. Data dikumpulkan menggunakan metode audio visual, yakni dengan melihat dan mendengar suatu objek dari gambar dan suara. Sementara itu, teknik pengumpulan data menggunakan teknik simak dan catat. Data dianalisis secara deskriptif sesuai dengan teori konsep eksistensi manusia Koeswara yang meliputi empat jenis, yakni kebersamaan dan cinta, pertentangan, keterasingan dan kesepian, serta kematian. Hasil penelitian menunjukkan bahwa konsep kebersamaan dalam film "Aisyah Biarkan Kami Bersaudara" karya Herwin Novianto meliputi keakraban, saling membantu/kerja sama, menasehati, rasa saling menghormati dan menghargai, perhatian, tanggung jawab, keterbukaan, rasa iba, tepa salira, berkeyakinan, serta berkelakar.
\end{abstract}

Kata kunci: konsep kebersamaan, cinta, film, Aisyah Biarkan Kami Bersaudara

\section{Abstract}

This study aims to describe the concept of togetherness in the film "Aisyah Biarkan Kami Bersaudara" by Herwin Novianto. This research is a qualitative research. Data is collected using audio visual methods, namely by seeing and hearing an object from pictures and sounds. Meanwhile, data collection techniques use the technique of listening and note taking. Data were analyzed descriptively according to Koeswara's concept of human existence which includes four types, namely togetherness and love, opposition, alienation and loneliness, and death. The results showed that the concept of togetherness in the film "Aisyah Biarkan Kami Bersaudara" by Herwin Novianto includes intimacy, mutual assistance / cooperation, advising, mutual respect and respect, attention, responsibility, openness, compassion, compassion, belief, and joked.

Keywords: concept of togetherness, love, films, Aisyah Biarkan Kami Bersaudara 


\section{Pendahuluan}

Sastra merupakan bagian dari manifestasi keadaan sosial kemasyarakatan. Karya sastra adalah suatu wujud yang mencerminkan perilaku, kejadian, keunikan, keberagaman masyarakat dalam setiap kurun waktu tertentu. Segala wujud cerminan masyarakat dapat digubah dalam sebuah sketsa karya sastra dengan tidak menghilangkan nilai rasa asli dari kenyataan yang terjadi dalam masyarakat.

Inovasi dalam sastra terus berkembang. Hal ini disebabkan sastra merupakan hasil penjumlahan atau ketegangan antara konvensi dan inovasi (Teeuw, 1980). Jika konvensi terlalu besar, sastra bersifat konvensional. Namun, kalau konvensi itu dikalahkan oleh inovasi, sastra dapat bersifat inkonvensional.

Dari dua masalah di atas, sastra semakin mengembangkan sayapnya dari yang bersifat tekstual hingga yang bersifat visual. Cerpen, novel, dan drama sekarang sudah dapat ditonton dalam bentuk film. Buku teori sastra masa kini, An Introduction to Literary Studies (1998) yang ditulis oleh seorang profesor bahasa Inggris pada Studi Amerika, Universitas Innsbruck, bernama Mario Klarer, secara khusus memasukkan genre film sebagai karya sastra. Dalam buku itu, Klarer juga membahas secara padat ihwal fiksi (fiction), puisi (poetry), drama, dan film. Pendapat Klarer mengenai film sebagai karya sastra dikutip berikut ini.

At the end of the twentieth century, it is impossible to neglect film as a semi-textual genre both influenced by and exerting influence on literature and literary critism. Film is predetermined by literary techniques, conversely, literary practice developed particular features under the impact of film. Many of the dramatic forms in the twentieth century, for example, have evolved in interaction with film, whose means of photographic depiction far surpass the means of realistic portrayal in the theater.

Film's idiosyncratic of presentation-such as camera angle, editing, montage, slow and fast motion-often parallel features of literary texts or can be explained within a textual framework (Klarer, 1998:57).

Menurut Mario Klarer, sebagaimana terdapat dalam kutipan di atas, film termasuk karya sastra dan segala macam mode presentasi film sesuai dengan fitur-fitur teks sastra dan dapat pula dijelaskan dalam kerangka tekstual. Dengan demikian, film adalah pergerakan kontemporer dari mode sastra tekstual ke mode sastra visual.

Karya sastra tidak terlepas dari eksistensi manusia. Tokoh-tokoh yang menjadi subjek atau pelaku dalam penceritaan akan mencerminkan karakter individu atau karakter sosial tertentu. Artinya, jika karya sastra tersebut berasal dari daerah bagian timur Indonesia, perwujudan eksistensi manusia tidak akan terlepas dari kebiasaan atau keadaan nyata masyarakat di sana.

Manusia, dengan eksistensi dan segala pengetahuan yang dimiliki, memungkinkan dapat beradaptasi dengan lingkungannya. Van der Weij (1988: 39) mengatakan bahwa manusia merupakan ciptaan Tuhan yang ada di muka bumi dan merupakan satu-satunya makhluk yang memiliki kemampuan berfikir dan merefleksikan segala sesuatu yang ada, termasuk diri dan keberadaannya di dunia. Kemampuan itulah yang membedakan manusia dengan makhluk lain, seperti binatang.

Karya sastra mempunyai dua aspek penting, yakni isi dan bentuk. Isi berupa pengalaman hidup manusia, sedangkan bentuk berupa cara penilaian, yaitu cara sastrawan memanfaatkan bahasa yang indah untuk mewadahi isinya (Semi, 1989: 8). Sementara itu, Pradopo (2003: 113) berpendapat bahwa karya sastra diciptakan oleh pengarang dengan tidak terlepas dari masyarakat dan budayanya. Sering kali sastrawan menonjolkan kekayaan budaya masyarakat, suku bangsa, atau bangsanya.

Hal yang sama terdapat dalam karya film. Sutradara film di Indonesia selalu menonjolkan eksistensi sosial budaya masyarakat dalam setiap karya mereka. Sebagai media hiburan dan wadah luapan ekspresi, film juga merupakan sarana pemaparan atas realitas sosial yang terjadi di kehidupan nyata. Secara visual film dapat menampilkan keadaan yang sangat mirip dengan yang sesungguhnya yang sedang terjadi di tengah-tengah masyarakat (Dila, 2017: 78).

Pada dasarnya antara sastra dan masyarakat terdapat hubungan yang hakiki. Menurut Ratna (2004: 60), hubungan itu terjadi 
disebabkan oleh (a) karya sastra diciptakan oleh pengarang; (b) pengarang itu sendiri adalah anggota masyarakat; (c) pengarang memanfaatkan kekayaan yang ada dalam masyarakat; dan (d) hasil karya itu dapat dimanfaatkan kembali oleh masyarakat.

Sastra tidak lahir dalam situasi kekosongan eksistensi manusia. Eksistensi menampakkan suatu keadaan masyarakat yang telah memiliki tradisi, adat istiadat, konvensi, keyakinan, pandangan hidup, cara hidup, cara berpikir, pandangan tentang astetika, dan lain sebagainya. Sastra dapat dipandang sebagai bagian integral dari kehidupan sosial budaya masyarakat yang melahirkannya. Selain itu, sastra muncul karena masyarakat menginginkan legitimasi kehidupan sosial budayanya, tepatnya legitimasi eksistensi kehidupannya. Sebagai disiplin yang berbeda, sastra dan sosial budaya memiliki objek yang sama, yakni manusia dalam masyarakat, manusia sebagai fakta sosial, manusia sebagai makhluk kultural.

Sementara itu, dalam penelitian ini, film "Aisyah Biarkan Kami Bersaudara" karya Herwin Novianto menjadi objek karena memiliki gambaran eksistensi manusia yang menyuguhkan cerita tentang persaudaraan (toleransi antarumat beragama) dan pendidikan. Film "Aisyah Biarkan Kami Bersaudara" menjalankan fungsinya sebagai cermin sosial dengan tokoh Aisyah dan anak-anak Nusa Tenggara Timur yang menjadi refleksi agar negeri ini tidak mudah terbelah atau terprovokasi.

Film "Aisyah Biarkan Kami Bersaudara" memaparkan keadaan secara realistis bagaimana wajah pendidikan Indonesia di daerah terpencil Indonesia serta perjuangan seorang guru yang menunjukkan jiwa nasionalis, survivor, dan pengabdian yang totalitas dengan tidak memedulikan masalah ras dan agama meskipun masalah ras dan agama tersebut masih menjadi permasalahan di masyarakat.

Herwin Novianto adalah sutradara film yang andal. Kemampuannya di dunia perfilman telah memberikan kontribusi yang besar bagi kemajuan perfilman yang berkualitas di Indonesia. Film "Aisyah Biarkan Kami
Bersaudara" merupakan salah satu film yang menggambarkan realita kehidupan sosial masyarakat daerah terpencil di pedalaman Nusa Tenggara Timur. Film yang diproduksi pada 2016 itu digarap oleh rumah produksi film One Productions dan diangkat dari kisah nyata seorang wanita muslim yang menjadi guru di sebuah desa terpencil: Dusun Derok, Kecamatan Biboki Anleu, Kabupaten Timur Tengah Utara, Provinsi Nusa Tenggara Timur, yang penduduknya mayoritas beragama Kristen.

Konsep kebersamaan merupakan bagian dari eksistensi manusia yang di dalamnya menunjukkan rasa cinta dan sayang manusia terhadap sesama. Menurut Abidin (2007: 1828), eksistensi dalam kehidupan manusia, antara lain, berupa (1) proses dinamis yang terjadi pada diri manusia; (2) pemberian makna; (3) esensi; (4) keautentik dan ketidakautentik; (5) kematian; (6) kecemasan; (7) kehendak bebas; (8) waktu; (9) ruang; (10) tubuh; (11) diri sendiri; (12) pilihan; dan (13) rasa bersalah.

Titik sentral persoalan dalam gerakan eksistensialisme adalah berbagai hal yang berubungan dengan eksistensi manusia. Berkaitan dengan hal itu, para tokoh eksistensialisme telah mengembangkan dan menguraikan berbagai pandangan menyangkut keberadaan serta kondisi-kondisi atau ciri-ciri fundamental yang ada pada manusia.

Menurut Koeswara (2002: 9), pandanganpandangan tersebut telah diterima dan disepakati secara luas untuk menjadi titik tolak atau tumpuan pikiran. Tidak saja bagi pikiran filosofis para eksistensialis, tetapi juga manjadi titik tolak bagi pemikir dan kegiatan praktis para ahli psikologis eksistensial.

Konsep atau pandangan tentang eksistensi manusia yang dimaksud oleh Koeswara (2002: 15) meliputi kebersamaan dan cinta; pertentangan; kesepian dan keterasingan; dan kematian.

Konsep eksistensi manusia tentang kebersamaan adalah suatu konsep filsafat yang sangat umum dan telah dikenal sejak manusia mengenal filsafat yang muncul sejak manusia itu sendiri menjalani kehidupan bersama. Para eksistensialis percaya bahwa kebersamaan atau hidup dengan sesama bagi manusia bukan 
semata-mata merupakan kebetulan atau hanya suatu realistis, melainkan merupakan sesuatu yang seharusnya ada sebab kebersamaan adalah ciri yang esensial dari keberadaan manusia. Hubungan cinta yang sungguh-sungguh dijalani oleh dua pihak yang saling membuka diri, saling percaya, dan saling terlibat sambil memelihara partner cinta sebagai pribadi atau subjek (Koeswara, 2002: 15).

Pertentangan adalah suatu hubungan manusia yang bukan merupakan kerja sama. Jadi, usaha untuk membangun cinta sebagai hubungan pribadi yang sungguh-sungguh merupakan usaha yang sia-sia saja sebab bilamana aku mengadakan kontak dengan orang lain, dengan serentak aku ingin mengobjekkan orang lain itu (Koeswara, 2002: 17)

Kesepian merupakan tema yang dapat dijumpai dalam berbagai sistem filsafat, dengan pemahaman yang berbeda-beda. Sebagai filsafat personalitis yang memandang individualitas manusia sebagai realitas dasar, eksistensialisme memandang kesepian sebagai kemungkinan manusia yang selalu ada atau bisa dialami dan tidak akan pernah terhapus. Para eksistensialis percaya bahwa kesepian bersumber pada kekosongan jiwa dan kesepian itu sendiri dialami individu-individu dengan berbagai bentuk perasaan yang mengikutinya, seperti rasa jenuh, takut, dan gelisah (Koeswara, 2002: 18).

\section{Metode Penelitian}

\subsection{Jenis Penelitian dan Pendekatan}

Penelitian ini adalah penelitian deskriptif kualitatif dengan menggunakan pendekatan filsafat sastra. Jenis penelitian deskriptif kualitatif merupakan salah satu prosedur penelitian yang menghasilkan data deskriptif berupa ucapan atau tulisan dan perilaku orangorang yang diamati (Bodgan dan Taylor dalam Moleong, 2007).

Sementara itu, pendekatan filsafat sastra digunakan untuk mengupas hakikat nilai-nilai kehidupan manusia yang terkandung dalam karya sastra.

\subsection{Metode dan Teknik Pengumpulan Data}

Metode yang digunakan dalam penelitian ini adalah metode audio visual, yakni dengan melihat dan mendengar suatu objek dari gambar dan suara. Sementara itu, teknik pengumpulan data menggunakan teknik simak. Teknik simak dilakukan oleh peneliti dengan menyimak dan melihat secara teliti keseluruhan film "Aisyah Biarkan Kami Bersaudara" karya Herwin Novianto yang berupa dialog dan gambargambar yang mencerminkan konsep kebersamaan dalam film "Aisyah Biarkan Kami Bersaudara" karya Herwin Novianto.

\subsection{Sumber dan Jenis Data}

Sumber data dalam penelitian ini adalah film "Aisyah Biarkan Kami Bersaudara" karya Herwin Novianto. Jenis data dalam penelitian ini adalah dialog dan gambar yang berupa kalimat dan adegan yang menggambarkan konsep kebersamaan dalam film "Aisyah Biarkan Kami Bersaudara" karya Herwin Novianto.

\subsection{Teknik Analisis Data}

Analisis data dalam penelitian ini dilakukan dengan tahapan sebagai berikut.

1. Pengidentifikasian data, yakni mengidentifikasi konsep kebersamaan melalui kalimat dan adegan antartokoh dalam film "Aisyah Biarkan Kami Bersaudara" karya Herwin Novianto.

2. Pengklasifikasian data, yakni mengklasifikasi kalimat dan adegan yang mencerminkan konsep kebersamaan dalam film "Aisyah Biarkan Kami Bersaudara" karya Herwin Novianto.

3. Penganalisisan data, yakni semua data yang telah diklasifikasi dianalisis dengan mendeskripsikan secara mendetail permasalahan yang ada dalam penelitian ini berupa konsep kebersamaan dalam film film "Aisyah Biarkan Kami Bersaudara" karya Herwin Novianto.

\section{Pembahasan}

Pembahasan dalam penelitian ini berupa pendeskripsian konsep kebersamaan dalam film "Aisyah Biarkan Kami Bersaudara” yang menjadi fokus masalah. 
Film "Aisyah Biarkan Kami Bersaudara" karya Herwin Novianto sarat dengan gambaran konsep kebersamaan dalam lingkungan masyarakat. Pengarang film memandang bahwa pendeskripsian kehidupan masyarakat yang mayoritas Kristiani menerima kedatangan minoritas (Islam) dalam keseharian mereka patut didokumentasikan.

Gambaran kehidupan sosial, budaya, dan kemasyarakatan masyarakat di bagian daerah terpencil Nusa Tenggara Timur terangkum dengan apik dalam film "Aisyah Biarkan Kami Bersaudara". Dalam mendeskripsikan konsep kebersamaan, penulis menggunakan teori konsep eksistensi manusia Koeswara yang meliputi empat jenis, yakni kebersamaan dan cinta, pertentangan, keterasingan dan kesepian, serta kematian.

Adapun eksistensi konsep kebersamaan dalam film "Aisyah Biarkan Kami Bersaudara" karya Herwin Novianto, yakni

\section{Konsep Kebersamaan dan Cinta}

Konsep kebersamaan dan cinta adalah sebuah gambaran keadaan manusia dalam sebuah hubungan yang positif. Dalam film "Aisyah Biarkan Kami Bersaudara" karya Herwin Novianto terdapat beberapa konsep kebersamaan dan cinta yang mengapikkan film tersebut. Berikut pembahasannya.

\section{Tabel 1}

Konsep Kebersamaan dan Cinta

\begin{tabular}{|l|l|}
\hline No. & $\begin{array}{c}\text { Konsep kebersamaan dan cinta dalam } \\
\text { film "Aisyah Biarkan Kami } \\
\text { Bersaudara" }\end{array}$ \\
\hline 1. & Keakraban \\
\hline 2. & Saling membantu dan kerja sama \\
\hline 3. & Menasehati \\
\hline 4. & $\begin{array}{l}\text { Rasa saling menghormati dan } \\
\text { menghargai }\end{array}$ \\
\hline 5. & Perhatian \\
\hline 6. & Tanggung Jawab \\
\hline 7. & Keterbukaan \\
\hline 8. & Rasa Iba \\
\hline 9. & Tepa salira \\
\hline 10. & Berkeyakinan \\
\hline 11. & Berkelakar \\
\hline
\end{tabular}

\section{Keakraban}

Keakraban adalah kedekatan hubungan yang lahir dari sifat sosial dalam masyarakat.
Keakraban yang tergambar dalam film "Aisyah Biarkan Kami Bersaudara" karya Herwin Novianto terlihat pada tokoh Aisyah saat memosisikan keakrabannya kepada semua orang, misalnya kepada ibunya, tetangga, sahabat, masyarakat di tempatnya mengajar. Keakraban merupakan bagian eksistensi manusia sebagai makhluk sosial.

Berikut ini contoh data dialog dalam film "Aisyah Biarkan Kami Bersaudara" yang menggambarkan kebersamaan dan cinta.

(1) Dialog Aisyah dengan tetangga

Aisyah : Pak, pagi Pak!

Tetangga 1 : Pagi Neng!

Tetangga 2 : Neng, tadi mama' nyariin Neng

Aisyah : O....gitu! Pak Dadang, Pak, nanti ba'da magrib jangan lupa datang ke sini ya

Pak Dadang : Insya Allah, Neng!

Aisyah : Matur nuwun Bapak!

(2) Dialog Aisyah dengan siswanya

Siswa 2 : Ibu guru dari Jawa-kah?

Aisyah : Iya sayang, Ibu dari Jawa Barat!

Siswa 3 : Di Jawa Barat, semua orang anggap Islam kayak Ibu?

Aisyah : Ngga juga, Thomas. Jadi, di Jawa Barat itu ada yang agamanya sama kayak kalian semua, Katholik, tapi ada juga yang Islam, tapi memang sebagian besar agamanya itu kebanyakan yang Islam.

Dua contoh percakapan di atas menggambarkan eksistensi manusia dalam hubungan keakraban antarsesama. Contoh (1) memperlihatkan keakraban Aisyah dengan tetangganya di Jawa Barat. Keakraban tampak ketika Aisyah saling menyapa dengan para warga saat berpapasan di jalan. Keakraban juga terlihat pada contoh (2), saat Aisyah membaur/mengakrabkan diri bersama para siswa tempatnya mengajar di Desa Atambua, Aisyah memosisikan dirinya untuk lebih aktif memberikan stimulus kepada para siswa. Hal itu dilakukan karena Aisyah melihat para siswa terlihat takut kepada orang asing, apalagi kepada penganut agama lain, yang berbeda dengan mereka.

\section{Saling Membantu/Kerja Sama}

Saling membantu adalah kegiatan timbal balik yang lahir secara rela dan ikhlas dalam 
kelompok masyarakat. Saling membantu yang tergambar dalam film "Aisyah Biarkan Kami Bersaudara" karya Herwin Novianto terlihat pada tokoh Aisyah dan tokoh-tokoh lain yang saling membantu dalam sebuah pekerjaan dan sumbangan pemikiran. Saling membantu merupakan bagian eksistensi manusia sebagai makhluk sosial.

Berikut ini contoh data narasi saling membantu dalam film "Aisyah Biarkan Kami Bersaudara".

(3) Aisyah bersama warga Dusun Derok membuat penampungan air bersih

Ketika mengetahui para siswa banyak yang tidak masuk sekolah akibat diare karena Dusun Derok dilanda musim kemarau sehingga persediaan air bersih semakin kurang, Aisyah tergerak hatinya untuk membuat penampungan air bersih. Aisyah bersama para siswa dan Pak Pedro pergi berlanja peralatan yang diperlukan dan bersama-sama warga membuat alat penampungan air bersih.

Ilustrasi contoh narasi film di atas menggambarkan eksistensi manusia dalam hubungan kerja sama antarsesama. Kepedulian Aisyah muncul karena warga Dusun Derok mengalami kekeringan akibat kemarau panjang yang berimbas pada kurangnya persediaan air bersih. Sementara itu, pengetahuan warga dusun tentang cara pembuatan penyaring air bersih masih sangat minim.

\section{Menasihati}

Menasihati adalah suatu anjuran, peringatan, ataupun teguran yang baik kepada seseorang atau kelompok. Menasihati yang tergambar dalam film "Aisyah Biarkan Kami Bersaudara" karya Herwin Novianto terlihat pada tokoh Aisyah dan tokoh-tokoh lain yang saling memberi teguran, masukan, dan anjuran yang positif. Menasihati merupakan bagian eksistensi manusia sebagai makhluk sosial.

Berikut ini contoh data menasihati dalam film "Aisyah Biarkan Kami Bersaudara".

(4) Aisyah menasehati para siswa tentang kerukunan beragama

Aisyah: Jadi, di Indonesia itubanyak sekali agamanya, walaupun agamanya berbeda, semuanya berdampingan dengan damai, dengan rukun karena penuh cinta, penuh kasih.
Siswa 1: Nah, Lordis bilang Islam itu musuh Kristen, dong suka perang.

Aisyah : Ya... memang suka ada yang berperang, tapi setiap agama, semua agama tidak pernah mengajarkan untuk penganut yang satu berperang atau bermusuhan dengan penganut lainnya.

Contoh (4) di atas menggambarkan eksistensi manusia dalam memberikan anjuran atau nasihat kepada sesama. Kepedulian Aisyah muncul karena warga Dusun Derok, khususnya para siswa, memiliki pemikiran yang negatif tentang agama Islam. Para siswa tersugesti oleh pemikiran seorang temannya yang mengatakan bahwa Islam itu musuh Kristen dan Islam itu agama yang suka berperang. Dengan kemampuannya sebagai seorang pendidik, Aisyah mengarahkan pola pikir para siswa ke arah yang lebih positif, yakni dengan memperkenalkan pentingnya saling menghormati dan menghargai dalam kerukunan beragama, ajaran-ajaran yang telah diajarkan dalam setiap agama.

\section{Rasa Saling Menghormati dan Menghargai}

Rasa saling menghormati dan menghargai adalah sikap timbal balik dari sekelompok orang yang saling memahami dan memberikan toleransi. Rasa saling menghormati dan menghargai yang tergambar dalam film "Aisyah Biarkan Kami Bersaudara" karya Herwin Novianto terlihat pada tokoh Aisyah dan tokoh-tokoh lain yang saling toleransi terhadap keyakinan mereka masing-masing. Rasa saling menghormati dan menghargai merupakan bagian eksistensi manusia sebagai makhluk sosial.

Berikut ini contoh data dialog dalam film "Aisyah Biarkan Kami Bersaudara" yang menggambarkan rasa saling menghormati dan menghargai.

(5) Siku, Pedro, dan Kepala Dusun menghormati dan menghargai keyakinan Aisyah dengan memberikan makanan yang halal.
Siku : Ibu guru Aisyah agama dia Islam bukan suster
Pedro : Siapa bilang suster?
Siku : Tadi Bapak Kepala Dusun bilang dia suster. Pingsan sudah dia 
K. Dusun : Katong tunggu Ibu guru bangun lalu katong makan bersama.

Siku : Tapi katong kasi makan Ibu apa? Orang Islam sunde makan daging babi na! A... katong kasi makan Ibu apa! (menunju ke dapur membuatkan mie instan untuk tokoh Aisyah)

Contoh (5) di atas menggambarkan eksistensi manusia dalam menghormati dan menghargai keyakinan sesama. Siku, Pedro, dan Kepala Dusun serta warga memperlihatkan rasa hormat mereka terhadap keyakinan yang dianut oleh Aisyah. Karena tidak mengetahui keyakinan Aisyah, tanpa sengaja warga menghidangkan daging babi. Namun, setelah mereka mengetahui agama Aisyah, Siku langsung bergegas membuatkan mi instan untuk Aisyah.

Film "Aisyah Biarkan Kami Bersaudara" mendeskripsikan berbagai rasa menghormati dan menghargai warga kepada Aisyah. Warga memperbolehkan tokoh Aisyah untuk pulang lebaran di kampungnya. Begitu pula Aisyah, bersama para siswa ia ikut membuat pohon natal untuk menyambut hari raya natal.

\section{Perhatian}

Perhatian adalah pemusatan psikis salah satu aspek psikologi yang tertuju pada suatu objek yang datang dari dalam dan luar individu. Perhatian yang tergambar dalam film "Aisyah Biarkan Kami Bersaudara" karya Herwin Novianto terlihat pada tokoh Aisyah dan tokohtokoh lain yang berupa tingkah laku dan rangsangan atau motivasi. Perhatian merupakan bagian eksistensi manusia sebagai makhluk sosial.

Berikut ini contoh data dialog dalam film "Aisyah Biarkan Kami Bersaudara" yang mempertlihatkan adanya perhatian.

(6) Siku merasa kasihan terhadap keadaan Aisyah yang terlihat lemas.

Aisyah : Siku, ada soal yang setengah mati to?

Siku : Sunde Ibu, beta su habis dari tadi

Aisyah : E... kenapa belum pulang?"

Siku : Beta mau pulang deng Ibu, kasian kalo Ibu pulang sendiri.

Contoh (6) di atas menggambarkan eksistensi manusia dalam memberikan perhatian kepada sesama. Siku memperlihatkan rasa kasihannya kepada Aisyah yang sejak awal terlihat kurang sehat. Siku menawari tokoh Aisyah untuk pulang bersama dari sekolah.

Film "Aisyah Biarkan Kami Bersaudara" mendeskripsikan berbagai rasa perhatian, baik warga kepada Aisyah maupun Aisyah kepada warga. Saat Aisyah sakit, misalnya, Siku membuatkan sarapan untuk Aisyah. Warga juga memberikan sumbangan kepada Aisyah agar bisa pulang kampung.

\section{Tanggung jawab}

Tanggung jawab adalah kesadaran manusia akan tingkah laku atau perbuatan yang disengaja maupun tidak disengaja. Tanggung jawab merupakan bagian eksistensi manusia sebagai makhluk sosial.

Berikut ini contoh data dialog dalam film "Aisyah Biarkan Kami Bersaudara" yang menggambarkan adanya rasa tanggung jawab.

(7) Aisyah bertanggung jawab atas tugasnya untuk mengabdikan diri pada salah satu sekolah terpencil di Dusun Derok.

Yohanes : Mohon maaf Ibu, untuk sementara kami belum bisa menyediakan kendaraan untuk Ibu. Jadi, sementara Ibu berjalan kaki dari rumah ke sekolah, demikian juga sebaliknya.

Aisyah : Gak apa-apa itu Pak, itu mah biasa untuk saya.

Contoh (7) di atas menggambarkan eksistensi manusia dalam menjalankan tanggung jawab pekerjaan. Aisyah memperlihatkan rasa tanggung jawabnya dan kecintaannya terhadap pekerjaaan. Aisyah rela berjalan kaki sejauh sepuluh kilo dari rumah ke sekolah demi pengabdiannya.

Film "Aisyah Biarkan Kami Bersaudara" mendeskripsikan berbagai rasa tanggung jawab warga kepada Aisyah begitu pula Aisyah kepada warga seperti saat Pedro merasa bertanggung jawab untuk menjemput dan selalu mendampingi Aisyah selama berada di Dusun Derok serta tanggung jawab Kepala Dusun untuk menghormati Aisyah saat berada di kampungnya.

\section{Keterbukaan}

Keterbukaan adalah keadaan yang memungkinkan ketersediaan informasi yang dapat diberikan dan didapat oleh masyarakat 
luas. Keterbukaan merupakan bagian eksistensi manusia sebagai makhluk sosial.

Film "Aisyah Biarkan Kami Bersaudara" mendeskripsikan berbagai sikap keterbukaan informasi, ilmu, dan pengalaman, baik warga kepada Aisyah maupun Aisyah kepada warga. Hal ini terlihat saat warga menjelaskan kepada Aisyah tentang keadaan kampung mereka baik kondisi alam, kondisi masyarakat yang masih kurang paham masalah ajaran Islam. Aisyah juga membagikan ilmunya kepada para siswa atau para warga, seperti tentang pentingnya menghargai orang yang berbeda agama dan mengenalkan ilmu sains dengan membuat penyaringan air bersih di Dusun Derok.

\section{Rasa Iba}

Rasa iba adalah bentuk rasa kasihan dengan apa yang dirasakan oleh orang lain. Rasa iba merupakan bagian eksistensi manusia sebagai makhluk sosial.

Film "Aisyah Biarkan Kami Bersaudara" mendeskripsikan berbagai sikap rasa iba, baik warga kepada Aisyah maupun Aisyah kepada warga. Rasa iba yang ditampakkan warga kapada Aisyah terjadi pada saat Aisyah ingin pulang kampung untuk merayakan lebaran Idulfitri. Karena biaya untuk pulang tidak cukup, warga memberikan sumbangan (berupa uang) untuk Aisyah.

Begitu pula Aisyah. Ia sangat iba terhadap keadaan psikologi Lordis yang selalu dihasut oleh pamannya untuk membenci Aisyah karena beragama Islam. Rasa tertekan Lordis itu membuat Aisyah ingin menolong Lordis agar keluar dari tekanan sang paman.

\section{Tepa Salira}

Tepa salira adalah suatu sikap yang dapat merasakan (menjaga) perasaan (bentuk pikiran) orang lain sehingga tidak menyinggung orang tersebut. Tepa salira merupakan bagian eksistensi manusia sebagai makhluk sosial.

Film "Aisyah Biarkan Kami Bersaudara" mendeskripsikan berbagai sikap tepa salira itu, baik antarwarga maupun Aisyah kepada warga. Tepa salira ditampakkan oleh Pedro saat menjaga perasaan kepala dusun yang merasa salah atas ketidaktahuannya terhadap agama yang dianut Aisyah. Pedro memosisikan diri sebagai orang yang bersalah terhadap kejadian tersebut. Sikap Pedro dalam kejadian ini merupakan bagian sikap tepa salira. Pedro ingin menyelamatkan rasa malu kepala dusun di depan warga.

Begitu pun Aisyah. Ia memiliki sikap tepa salira, yakni menjaga perasaan istri kepala dusun saat Aisyah mendengar suara lengkingan anak-anak babi yang ada di pekarangan. Aisyah mencoba menutupi rasa jijiknya.

\section{Berkeyakinan}

Berkeyakinan merupakan bagian eksistensi manusia sebagai makhluk sosial. Apa pun bentuknya, seseorang atau sekelompok orang dapat dipastikan mempunyai keyakinan atau kepercayaan.

Film "Aisyah Biarkan Kami Bersaudara" mendeskripsikan adanya keyakinan atau kepercayaan warga desa dan Aisyah. Warga desa pememluk Kristen, sedangakan Aisyah pemeluk Islam. Warga desa melakukan kegiatan-kegiatan keagamaan sesuai dengan ajaran Kristen (seperti berdoa di tempat ibadah, memasang gambar Yesus di rumah), Aisyah pun melaksanakan ibadah sesuai dengan keyakinannya, yakni Islam. Dia melaksanakan puasa ramadan dan shalat wajib.

\section{Berkelakar}

Berkelakar adalah bercakap-cakap tidak dengan sungguh-sungguh (hanya bergurau atau berolok-olok). Berkelakar merupakan bagian eksistensi manusia sebagai makhluk sosial.

Berikut ini contoh data dialog dalam film "Aisyah Biarkan Kami Bersaudara" yang memperlihatkan kelakar.

(8) Tokoh Pedro berkelakar di depan Aisyah dan para siswa.

Pedro : Baru kapan mau pigi belanja ke Atambua? Nanti gue antar

Siswa : Saya ikut, saya ikut, saya ikut (sambil bersamaan unjuk jari)

Pedro : E...e...lu ikut, lu ikut, lu tinggal, belum cukup umur (menunjuk siswa yang satu)

siswa 1 : Tapi sa satu kelas

Pedro : Tapi pung tinggi belum sampe.

Contoh (8) di atas menggambarkan eksistensi manusia pada saat bercanda atau berkelakar. Sikap tersebut berfungsi untuk 
menghibur lawan tuturnya. Pedro berkelakar kepada Aisyah dan para siswa agar menambah suasana bahagia dan riang.

Film "Aisyah Biarkan Kami Bersaudara" mendeskripsikan berbagai peristiwa candaan, seperti saat Pedro dimarahi oleh istrinya karena lupa dengan pesanan sang istri. Candaan juga terjadi pada saat Aisyah melakukan tanya jawab kepada para siswa. Karena salah menjawab pertanyaan Aisyah, para siswa justru saling menyalahkan.

\section{Penutup}

Berdasarkan penelitian yang telah dilakukan, dapat disimpulkan beberapa hal yang terkait dengan konsep eksistensi manusia dalam film "Aisyah Biarkan Kami Bersaudara" karya Herwin Novianto.

Terdapat tiga konsep eksistensi manusia dalam film "Aisyah Biarkan Kami Bersaudara" karya Herwin Novianto, yakni (1) konsep kebersamaan dan cinta; (2) konsep pertentangan; serta (3) konsep keterasingan dan kesepian.

Konsep kebersamaan dan cinta merupakan gambaran keadaan manusia dalam sebuah hubungan yang positif yang ditampakkan melalui sikap suatu individu kepada individu yang lain. Bentuk konsep kebersamaan dan cinta dalam film "Aisyah Biarkan Kami Bersaudara" karya Herwin Novianto meliputi keakraban, saling membantu/kerja sama, menasehati, rasa saling menghormati dan menghargai, perhatian, tanggung jawab, keterbukaan, rasa iba, tepa salira, berkeyakinan, serta berkelakar.

\section{Daftar Pustaka}

Abidin, Zainal. 2007. Analisis Eksistensial, Sebuah Pendekatan Alternatif untuk Psikologi dan Psikiatri. Jakarta: PT Raja Grafindo.

Susiati, S. (2020). Fenomena Tuturan Emosi Verbal Bahasa Indonesia Suku Bajo Sampela.

Bagus, Lorens. 2005. Kamus Filsafat. Jakarta: Gramedia Pustaka Utama.
Andini, K. NILAI BUDAYA SUKU BAJO SAMPELA DALAM FILM THE MIRROR NEVER LIES KARYA KAMILA ANDINI.

Susiati, S. (2020). Konsep Pertentangan Dalam Film" Aisyah Biarkan Kami Bersaudara" Karya Herwin Novianto.

Susiati, S. (2020). Strategi AMBT untuk Meningkatkan Kemampuan Membaca Pemahaman Interpretatif Siswa Kelas IV SD Negeri 3 Namlea Kabupaten Buru.

Susiati, S. (2020). Fungsi Konatif Pada Iklan Mesin Cuci Hole-Less Tub Dari Sharp: Analisis Wacana Kritis.

Dila, Putri Andini Kusumawardani. 2017. "Gambaran Eksistensi Tokoh Sandra dalam Film Deux Jours Une Nuit Karya Jean-Plerre Dardenne dan Luc Dardenne: Kajian Psikologi Eksistensial". Thesis. Universitas Brawijaya.

Susiati, S. (2020). GAYA BAHASA SECARA UMUM DAN GAYA BAHASA PEMBUNGKUS PIKIRAN.

Susiati, S. (2020). Konsep Kebersamaan Dalam Film" Aisyah Biarkan Kami Bersaudara" Karya Herwin Novianto.

Susiati, S. (2020). Teori dan Aliran Linguistik: Tata Bahasa Generatif.

Indonesia, K. K. D. B. Morfologi Bahasa Indonesia.

Djojosuroto, Kinayati. 2007. Filsafat Bahasa. Yogyakarta: Pustaka Book.

Susiati, S. (2020). Metode Pembelajaran Bahasa Indonesia: Sosiodrama.

Susiati, S. (2020). Rekontruksi Internal Bahasa Bugis dan Bahasa Makassar: Linguistik Komparatif. 
Klarer, Mario. 1998. An Introduction to Literary Studies. London: Routledge.

Susiati, S. Bahan Ajar: Psikolinguistik.

Koeswara. 2002. Psokologi Eksistensial Suatu Pengantar. Bandung: Rosda Offset.

Moleong, Lexi. 2007. Metodologi Penelitian Kualitatif. Bandung: Remaja Rosdakarya.

Pradopo, Rahmat Djoko. 2003. Prinsip-prinsip Kritik Sastra. Yogyakarta: Gadjah Mada University Press.

Ratna, Nyoman Kutha. 2004. Paradigma Sosiologi Sastra. Yogyakarta: Pustaka Pelajar.

Semi, M. Atar. 1989. Kritik Sastra. Bandung: Angkasa.

Sumarno, Marseli. 1996. Dasar-dasar Apresiasi Film. Jakarta: PT Grasindo

Tafsir, Ahmad. 2006. Filsafat Pendidikan Islami. Jakarta: PT Remaja Rosdakarya.

Amanto, B. S., Umanailo, M. C. B., Wulandari, R. S., Taufik, T., \& Susiati, S. (2019). Local Consumption Diversification. Int. J. Sci. Technol. Res, 8(8), 1865-1869.

Susiati, S. (2020, June 18). Eksistensi Manusia Dalam Film "Aisyah Biarkan Kami Bersaudara" Karya Herwin Novianto. https://doi.org/10.31813/gramatika/7.1.2019.1 73.50--63

Iye, R., \& Susiati, S. (2018). NILAI EDUKATIF DALAM NOVEL SEBAIT CINTA DI BAWAH LANGIT KAIRO KARYA MAHMUD JAUHARI ALI (Educative Values in Sebait Cinta di Bawah Langit Kairo by Mahmud Jauhari Ali). Sirok Bastra, 6(2), 185-191.

Susiati, S., \& Iye, R. (2018). Kajian Geografi Bahasa dan Dialek di Sulawesi Tenggara: Analisis Dialektometri. Gramatika: Jurnal Ilmiah Kebahasaan dan Kesastraan, 6(2), 137151.
Iye, R., Susiati, S., \& Karim, K. (2020). Citra Perempuan dalam Iklan Sabun Shinzui. Sang Pencerah: Jurnal Ilmiah Universitas Muhammadiyah Buton, 6(1), 1-7.

Susiati, S., Iye, R., \& Suherman, L. O. A. (2019). Hot Potatoes Multimedia Applications in Evaluation of Indonesian Learning In SMP Students in Buru District. ELS Journal on Interdisciplinary Studies in Humanities, 2(4), 556-570.

Susiati, S. (2018). Homonim bahasa kepulauan tukang besi dialek kaledupa di kabupaten wakatobi [the homonymon of tukang besi island languange in kaledupa dialect at wakatobi regency]. Totobuang, 6 (1), 109, 123.

Nurhayati, N., \& Said, I. (2019). Emosi Verbal Suku Bajo Sampela. Sosial Budaya, 16(2), 114126.

Susiati, S., \& Iye, R. (2018). Kajian Geografi Bahasa dan Dialek di Sulawesi Tenggara: Analisis Dialektometri. Gramatika: Jurnal Ilmiah Kebahasaan dan Kesastraan, 6(2), 137151.

Susiati, S. (2020). Kaidah Fonologi Bahasa Indonesia.

Harziko, H., Said, I. M., \& Darwis, K. (2018). FOLLOW THE EVENTS IN THE INDONESIAN LANGUAGE EXPRESSIVE SAID TRANSACTION IN THE TRADITIONAL MARKET TOWN OF BAUBAU. JURNAL ILMU BUDAYA, 6(1).

Susiati, S. (2020). Pengaplikasian Multimedia Hot Potatoes Dalam Evaluasi Pembelajaran Bahasa Indonesia Pada Siswa SMP Negeri 9 Buru.

Susiati, S. (2020). Fenomena Tuturan Emosi Verbal Bahasa Indonesia Suku Bajo Sampela.

Andini, K. NILAI BUDAYA SUKU BAJO SAMPELA DALAM FILM THE MIRROR NEVER LIES KARYA KAMILA ANDINI. 
Susiati, S. (2020). Nilai Budaya Suku Bajo Sampela Dalam Film The Mirror Never Lies Karya Kamila Andini.

Said, I. EMOSI VERBAL SUKU BAJO SAMPELA.

Susiati, S. (2020). Metode Pembelajaran Bahasa Indonesia: Sosiodrama.

Tahir, S. Z. B., Atmowardoyo, H., \& Dollah, S. (2018). BELAJAR BERBICARA MULTIBAHASA UNTUK SANTRI PESANTREN. Yogyakarta, Deepublish.

Susiati, S. (2020). Morfologi Kelas Kata Dalam Bahasa Indonesia.

Susiati, S. (2020). Fenomena Tuturan Emosi Verbal Bahasa Indonesia Suku Bajo Sampela.

Tenriawali, A. Y. (2018). Representasi korban kekerasan dalam teks berita daring tribun timur: analisis wacana kritis [the representation victims of violence in tribun timur online news text: critical discourse analysis]. TOTOBUANG, 6 (1), 1, 15.

Susiati, S., \& Iye, R. (2018). Kajian Geografi Bahasa dan Dialek di Sulawesi Tenggara: Analisis Dialektometri. Gramatika: Jurnal Ilmiah Kebahasaan dan Kesastraan. 6 (2), 137151.

Djamudi, N. L., Nurlaela, M., Nazar, A., Nuryadin, C., Musywirah, I., \& Sari, H. (2019, October). Alternative social environment policy through educational values in Kafi'a's customary speech to the kaledupa community of Wakatobi Island, Indonesia. In IOP Conference Series: Earth and Environmental Science (Vol. 343, No. 1, p. 012118). IOP Publishing.

Susiati, S. (2020). Gaya Bahasa Secara Umum Dan Gaya Bahasa Pembungkus Pikiran: Stilistika.

Susiati, Y. T. Risman Iye. A. Kesantunan Imperatif Bahasa Indonesia Suku Bajo Sampela: Balai Pembinaan dan Pengembangan
Bahasa. 2018. Kongres Bahasa Indonesia (No. 12, pp. 1-6). Report.

Susiati, S. (2020). Kesantunan Imperatif Bahasa Melayu Ambon.

Mufidah, N., \& Tahir, S. Z. B. (2018). Empowering E-Learning As An Interactive Teaching For Arabic Learners. Lisanudhad, 5(2), 57-72.

Susiati, S. (2020). Gaya Bahasa Secara Umum Dan Gaya Bahasa Pembungkus Pikiran: Stilistika.

Yusdianti, $\quad$ A. $\quad$ (2020). THE REPRESENTATION VICTIMS OF VIOLENCE IN TRIBUN TIMUR ONLINE NEWS TEXT: CRITICAL DISCOURSE ANALYSIS.

Susiati, S. (2020). Tuturan Kesantunan Imperatif Bahasa Indonesia Suku Bajo Sampela.

Nacikit, J. PENTINGNYA MELESTARIKAN BAHASA DAERAH.

Susiati, S. (2020). Wujud Morfologi Bahasa Indonesia.

Susiati, S. (2020). Nilai Budaya Suku Bajo Sampela Dalam Film The Mirror Never Lies Karya Kamila Andini.

Taufik, T. (2019). Strategi AMBT untuk Meningkatkan Kemampuan Membaca Pemahaman Interpretatif Siswa Kelas IV SD Negeri 3 Namlea Kabupaten Buru. Sang Pencerah: Jurnal Ilmiah Universitas Muhammadiyah Buton, 5(2), 53-62.

Susiati, S. (2020). Morfologi Kelas Kata Dalam Bahasa Indonesia.

Rahayu, T. (2019). DIKSI DAN GAYA BAHASA PADA CERPEN ANAK DALAM MAJALAH MOMBI. Jurnal Pendidikan dan Pembelajaran Bahasa Indonesia, 8(2), 79-87.

Susiati, S. (2020). Kaidah Fonologi Bahasa Indonesia. 
Afrianti, I. H., Chanafiah, Y., \& Agustina, E. ANALISIS TOKOH DALAM NOVEL JEJAK KUPU-KUPU KARYA AGNES JESICA DENGAN TINJAUAN PSIKOLOGI SASTRA (Doctoral dissertation, Universitas Bengkulu).

Susiati, S. (2020). PENTINGNYA MELESTARIKAN BAHASA DAERAH.

Wardani, Y., Priyadi, T., \& Sanulita, H. Struktur dan Makna Mantra Bekumpang Sastra Lisan Dayak Kantuk (Doctoral dissertation, Tanjungpura University).

Susiati, S. (2020). Makian Bahasa Wakatobi Dialek Kaledupa.

Siregar, J. A. K., Malik, A., \& Lestari, D. (2020). KEARIFAN LOKAL CERITA RAKYAT MASYARAKAT KABUPATEN KARIMUN KEPULAUAN RIAU. Jermal, 1(1), 1-14.

Susiati, S. (2020). Rekontruksi Internal Bahasa Bugis dan Bahasa Makassar: Linguistik Komparatif.

Basuki, N. V. A., \& Mulyono, M. (2018). Pengaruh Pelecehan Seksual Terhadap Pembentukan Perilaku Transgender pada Tokoh Sasana dalam Novel Pasung Jiwa Karya Okky Madasari: Kajian Psikologi Sastra. Jurnal Sastra Indonesia, 7(2), 95-100.

Susiati, S. (2020). Embrio Nasionalisme Dalam Bahasa dan Sastra.

Septarianto, T. W. (2018, November). MANISFESTASI NILAI-NILAI KEARIFAN LOKAL DALAM BUKU CERITA ANAK KECIL-KECIL PUNYA KARYA (KKPK)"LILI \&LYLIU”. In Seminar Internasional Riksa Bahasa (pp. 829-836).

Leja, W. NILAI PEMBENTUK KARAKTER MASYARAKAT WAKATOBI MELALUI KABHANTI WA LEJA.

Susiati, S. (2020). Teori dan Aliran Linguistik: Tata Bahasa Generatif.
Wahyuni, S. (2018). HUMOR DAN PESAN MORAL TEKS ANEKDOT PADA BUKU AJAR BAHASA INDONESIA KELAS $X$ SMA KURIKULUM 2013 (HUMOR AND MORAL MESSAGE OF ANECDOTAL TEXTS IN INDONESIAN LANGUAGE TEACHING MATERIALS FOR THE TENTH GRADE OF 2013 CURRICULUM SENIOR HIGH SCHOOL). JURNAL BAHASA, SASTRA DAN PEMBELAJARANNYA (JBSP), 7(2), 245-258.

Susiati, S. (2020). Semantik: Teori Semantik, Relasi Makna, Marked, Dan Unmarked.

Singgih, M., \& Surastina, S. (2019, June). NILAI-NILAI RELIGIUS DALAM NOVEL BIDADARI BERMATA BENING KARYA HABIBURRAHMAN EL-SHIRAZY DAN IMPLIKASINYA DI SEKOLAH. In Prosiding Seminar Nasional STKIP PGRI Bandar Lampung (pp. 215-222).

Susiati, S. (2020). Metode Pembelajaran Bahasa Indonesia: Sosiodrama.

Nugroho, R., \& Sunanda, A. (2019). Pendidikan Karakter dalam Novel Ratu Nyontek Karya Teresa Bertha: Tinjauan Sosiologi Sastra dan Relevansinya dalam Pembelajaran di SMA (Doctoral dissertation, Universitas Muhammadiyah Surakarta).

Susiati, S. PERWUJUDAN SIMILE OLEH MERARI SIREGAR DALAM NOVEL AZAB DAN SENGSARA.

Susiati, S. (2020, June 21). Bahan Ajar: Psikolinguistik.

https://doi.org/10.31219/osf.io/9hveb

Susiati, S. (2020). GAYA BAHASA SECARA UMUM DAN GAYA BAHASA PEMBUNGKUS PIKIRAN.

Teeuw, A. 1984. Sastra dan Ilmu Sastra: Pengantar Teori Sastra. Jakarta: Pustaka Jaya.

Susiati, S. (2020). Gaya Bahasa Secara Umum Dan Gaya Bahasa Pembungkus Pikiran: Stilistika. 
Van der Weij, P. A. 1988. Filsuf-Filsuf Besar tentang Manusia (Terj.: K. Bertens). Gramedia: Jakarta.

Susiati, S. (2020). Emosi Verbal Suku Bajo Sampela. 